\title{
Pengaruh YouTube Atta Halilintar Terhadap Motivasi Bagi Mahasiswa
}

\author{
Agnita Eriyawati \\ Universitas Singaperbangsa Karawang \\ agnita.eriyawati98@gmail.com \\ Mayasari \\ Universitas Singaperbangsa Karawang \\ M. Ramdhani \\ Universitas Singaperbangsa Karawang
}

\begin{abstract}
Abstrack
The development of technology is progressing with the emergence of a new media today, such as social media which is one of the main needs for those who use it, social media has now developed a new media, one of which is YouTube which is currently more in demand by social media users, because YouTube is one of the more effective media than other media by presenting sources of past information to the present, presenting a knowledge, entertainment even, can make an income. The title of this research is "The Effect of YouTube Atta Halilintar Impressions on Motivation to be Youtubers for Communication Science Students" The purpose of this study is to find out how much influence that occurs between Intensity X1 V ariables, Message X2 Contents and X3 Attraction on YouTube Atta Halilintar Impressions towards motivation motivation to be a YouTuber. The method used in this research is to use a quantitative approach with multiple regression analysis. The population used in this study were students of the Communication Studies Program at the University of Singapore Karawang University 2017-2019 with samples taken by researchers, namely students who have watched YouTube shows Atta Halilintar as many as 81 students through cluster sampling techniques because the population used in this study was a group of students from 2017-2019. Data collection techniques using questionnaires and literature study. This study uses Albert Bandura's social learning theory The results showed that the subvariables for the intensity, content of the message and the attractiveness of YouTube shows atta Halilintar simultaneously had a significant effect and for the results carried out partial determination the results were obtained for an intensity of $0.56 \%$ the message content of $3.88 \%$ and a pull of $16,48 \%$
\end{abstract}

Keywords: Impressions, YouTube, motivation

Jurnal Dakwah dan Komunikasi

IAIN Curup-Bengkulu | E-ISSN : 2548-3366, P-ISSN:2548-3293 


\begin{abstract}
Abstrak
Perkembangan teknologi semakin maju dengan adanya sebuah media baru yang muncul saat ini, seperti media sosial yang menjadi salah satu kebutuhan utama bagi yang menggunakannya, media sosial saat ini telah mengembangkan suatu media baru, salah satunya YouTube yang saat ini lebih banyak diminati oleh pengguna media sosial, karena YouTube menjadi salah satu media yang lebih efektif dibanding media lain dengan menyajikan sumber informasi lampau hingga masa kini, menyajikan suatu pengetahuan, hiburan bahkan, bisa menjadikan suatu penghasilan. Adapun judul penelitian ini adalah "Pengaruh Tayangan YouTube Atta Halilintar terhadap Motivasi menjadi Youtuber bagi Mahasiswa Ilmu Komunikasi" Tujuan dalam penelitian ini adalah untuk mengetahui seberapa besar pengaruh yang terjadi antara SubVariabel Intensitas $\mathrm{X}_{1}$, Isi Pesan $\mathrm{X}_{2}$ dan Daya Tarik $\mathrm{X}_{3}$ mengenai Tayangan YouTube Atta Halilintar terhadap motivasi motivasi menjadi YouTuber. Adapun metode yang dipakai dalam penelitian ini adalah menggunakan metode pendekatan kuantitatif dengan analisis regresi berganda. Populasi yang digunakan pada penelitian ini adalah Mahasiswa Program Studi Ilmu Komunikasi Universitas Singaperbansa Karawang Angkatan 2017-2019 dengan sampel yang diambil oleh peneliti yaitu mahasiswa yang pernah menonton tayangan YouTube Atta Halilintar sejumlah 81 mahasiswa melalui teknik pengambilan cluster sampling karena populasi yang dipakai pada penelitian ini merupakan sekelompok mahasiswa Angkatan 2017-2019. Teknik pengumpulan data menggunakan penyebaran kuesioner dan studi kepustakaan. Penelitian ini menggunakan teori pembelajaran sosial Albert Bandura. Hasil penelitian menunjukan bahwa subvariabel untuk intensitas,isi pesan dan daya Tarik tayangan YouTube Atta Halilintar secara simultan berpengaruh signifikan dan untuk hasil yang dilakukan secara determinasi parsial diperoleh hasil untuk intensitas sebesar $0,56 \%$ isi pesan sebesar 3,88\% dan daya Tarik sebesar 16,48\%
\end{abstract}

Kata Kunci: Tayangan, YouTube, Motivasi

\title{
Pendahuluan
}

Pada hakikatnya manusia atau makhluk sosial harus melakukan proses interaksi atau proses bersosialisasi terhadap sesama manusia lainnya. Komunikasi sendiri adalah,suatu bentuk interaksi antara manusia satu dengan manusia lainnya yang dilakukan baik secara sengaja ataupun tidak sengaja, komunikasi tidak terbatas pada bentuk komunikasi verbal saja, namun juga bisa nonverbal seperti komunikasi lewat bentuk ekspresi muka, seni, lukisan dan teknologi. Menurut Harold Laswell dalam buku Dedy Mulyana cara yang baik untuk menggambarkan komunikasi adalah dengan menjawab pertanyaanpertanyaan (Who Says? what? In which channel? To whom? With what effect?) atau 
siapa mengatakan, apa, dengan saluran apa, kepada siapa dengan pengaruh bagaimana ${ }^{1}$

Perkembangan teknologi merupakan sesuatu yang tidak bisa kita hindari dalam kehidupan ini, kemajuan teknologi sangat berpengaruh terhadap kehidupan manusia. Munculnya sebuah media baru timbul karena teknologi yang begitu canggih. Teknologi sendiri telah memiliki perkembangan berupa alat-alat canggih yang lebih efektif dibandingkan dengan teknologi sebelumnya. Saat ini teknologi memang terbilang sangat dibutuhkan seperti halnya teknologi baru mengenai penggunaan media sosial yang dimana semua pengguna dapat berinteraksi kepada pengguna media lain dalam jarak jauh. Media sosial sendiri harus memiliki jaringan untuk dapat mengaksesnya, yaitu jaringan internet yang merupakan sebuah teknologi baru di dunia

Menurut Hootsuite (We are Social): Indonesian Digital Report 2019 Hootsuite menyajikan mengenai hasil presentase sesuai data dan tren yang dibutuhkan seperti hasil presentase dari data internet, media sosial ditiap tahunnya. Hootsuite menerbitkan data tren mengenai internet, media sosial biasanya pada akhir bulan pertama setiap tahunnya, seperti pada tahun 2019 dan kemudian Hootsuite dapat mengeluarkan data tersebut pada akhir Januari 2019. Berikut data Tren Internet dan Media sosial 2019 di Dunia menurut Hootsuite : Total Populasi (jumlah penduduk): 268,2 juta (naik 1\% atau sekitar 3 juta populasi dari tahun 2018), Pengguna Mobile Unik: 355,5 juta (turun 19\% atau sekitar 83 juta dari tahun 2018), Pengguna Internet: 150 juta (naik 13\% atau sekitar 17 dari tahun 2018), Pengguna Media Sosial Aktif: 150 juta (naik 15\% atau sekitar 20 dari tahun 2018), Pengguna Media Sosial Mobile: 130 juta (naik 8,3\% atau sekitar 10 dari tahun 2018) ${ }^{2}$

Masyarakat pun kebanyakan mengakses internet untuk keperluan mereka di media sosial. Adapun definisi media sosial ialah sebagai serangkaian kegiatan yang mengintegrasikan penggunaan teknologi dan interaksi sosial untuk berbagi pembicaraan, gambar, video dan suara, sedangkan menurut Williamson (dalam Widjajanto, 2013:143) media sosial adalah sebagai media yang didesain untuk menyebarkan pesan melalui interaksi sosial dengan teknik - teknik publikasi yang sangat mudah di akses dimanapun dan kapanpun dan dalam skala besar ${ }^{3}$

Media sosial adalah medium atau wadah untuk bersosialisasi dengan menggunakan teknologi berbasis web untuk menyebarluaskan secara pengetahuan dan informasi secara cepat kepada seluruh pengguna internet didunia. Media sosial merupakan media online yang meliputi blog, jejaring sosial, wiki, forum, dan dunia virtual yang sangat berguna dan bermanfaat pada era modern seperti saat ini. Dengan adanya media sosial kita dapat mencari informasi yang sangat bermanfaat dan menarik minat kita untuk mengetahui

1 Mulyana, Deddy. Ilmu Komunikasi Suatu Pengantar. (Bandung : Remaja Rosdakarya, 2012),69

${ }^{2}$ Hootsuite (We are Social): Indonesian Digital Report 2019

3 Widjajanto, Kenmada, dkk. Perencanaan Komunikasi : Konsep Dan Aplikasi. (Bandung : Ultimus, 2013),143 
lebih dalam tentang suatu hal. Kehadiran media sosial kini lebih banyak digunakan oleh masyarakat Indonesia seperti media YouTube yang sangat popular saat ini, karena YouTube sendiri telah memberikan effek yang cukup besar kepada hampir seluruh masyarakat Indonesia, YouTube sendiri merupakan suatu media yang terbilang lebih efektif dibanding dengan media yang lain, youtube sendiri telah memberikan suatu hal yang unik berupa hiburan yang disajikan oleh content creator/channel YouTube lainnya, bahkan YouTube dapat menyajikan informasi-informasi/pengetahuan menarik baik lampau atau masa kini. Saat ini media sosial dapat menggeser eksistensi media-media konvensional.

YouTube pertama kali hadir pada 14 Februari 2005, Pada tahun 2011, YouTube menduduki peringkat pertama untuk situs video sharing. Media sosial YouTube merupakan media sosial yang paling banyak digunakan di Indonesia pada tahun 2017. CEO YouTube Susan Wojcicki mengungkapkan di tahun 2018 ada 1,8 miliar pengguna YouTube terdaftar yang menyaksikan video di platform tersebut setiap bulannya. Angka tersebut meningkat dibandingkan data sebelumnya pada pertengahan 2017 sebesar 1,5 miliar penonton yang login akun YouTube per bulan. Dilihat dari banyak nya audiens yang mengakses media sosial YouTube tersebut maka sangat menguntungkan bagi content creator atau youtuber.

Salah satu youtuber yang menarik perhatian saat ini ialah Atta Halilintar Muhammad Attamimi Halilintar atau lebih dikenal dengan nama Atta Halilintar, merupakan anak sulung dari keluarga Gen Halilintar (Halilintar Anofial Asmid dan Lenggogeni Faruk). Atta lahir tanggal 20 November 1994 di Dumai. Di awal karirnya Atta mulai berbisnis dengan menjual makanan dan mainan, karena bisnis orang tuanya sempat mengalami kesulitan saat tinggal di Malaysia. Pada saat itu Atta telah membuka channel YouTube pribadinya dengan nama Atta Halilintar

28 April 2020 jumlah pengikut atau subscriber yang ada di channel Atta Halilintar sudah mencapai 22,4 Juta Subscriber, 796 video yang di unggahnya dan jumlah viewers 2,2 Miliar dan itu adalah angka yang sangat besar yang ada di dunia per-YouTuban Indonesia. Atta juga berhasil melewati jumlah subscriber paling tinggi pertama kali di Indonesia, yaitu Raditya Dika. Kesuksesan Atta yang sudah diraih sekarang itu berkat kerja keras dan usaha yang ia lakukan dari kecil sampai sekarang dan juga faktor dukungan dari ke dua orang tuanya. Ia juga sering memberikan motivasi-motivasi di setiap videonya untuk para penontonnya atau ATeam (nama penggemar Atta) dan itu membuat ia disukai oleh orang-orang. Atta Halilintar telah mendapatkan 3 plakat dari YouTube seperti Silver Play Button karena pencapaian awal menjadi seorang content creator yang menembus 100 ribu subscriber, kedua, Gold Play Button, pencapaian untuk mendapatkan Gold Play Button adalah dapat mencapai 1 juta subscriber, dan yang ketiga adalah Diamond Play Button, dimana plakat ini tentunya diinginkan oleh para youtuber lain, untuk mendapatkan Diamond Play Button adalah dengan mencapai jumlah subscriber sebanyak 10 juta. Kini Atta telah memiliki ketiga 
Play Button yang dipersembahkan dari YouTube kepadanya karena pencapaiannya yang telah sukses mendapatkan jumlah subscriber terbanyak

Di awal membuat video di YouTube, Atta memulai dengan kontenkonten vlog atau lebih sering disebut dengan Daily Vlog, yaitu menceritakan atau merekam tayangan berupa aktifitasnya dan mengunggahnya ke channel YouTube pribadinya. Tayangan sendiri adalah sesuatu yang ditayangkan (dipertunjukan), tayangan merupakan kegiatan berupa informasi atau isi pesan atau bahkan hiburan yang dapat dipertunjukan kepada khalayak. Jadi tayangan dapat diartikan sesuatu yang dipertunjukan kepada khalayak berupa berita, informasi, hiburan dan sebagainya melalui media elektronik, seperti tayangan video YouTube Atta Halilintar yang berisi daily vlog nya yang menarik, tayangan prank, music sosial eksperimen sampai tayangan video motivasi yang diunggah ke channel YouTube pribadinya.

Adapun latar belakang penelitian "Pengaruh YouTube Atta Halilintar Terhadap Motivasi Menjadi Seorang Youtuber bagi Mabasiswa Ilmu Komunikasi UNSIKA 2017-2018" dibuat, karena pada zaman ini millenials lebih tertarik menggunakan media YouTube sebagai sumber informasi, pengetahuan bahkan sampai hiburan. YouTube sendiri terbilang lebih efektif untuk digunakan dan dapat di pergunakan dimana saja dan kapan saja, saat ini menjadi seorang Youtuber dapat memberikan kesuksesan hanya dengan bermodalkan akun/channel YouTube, kamera, dan tentunya rasa percaya diri untuk mencapai apa yang diinginkan

Adapun identifikasi masalah pada penelitian ini adalah:

1. Seberapa besar pengaruh intensitas YouTube Atta Halilintar terhadap motivasi menjadi seorang Youtuber

2. Seberapa besar pengaruh isi pesan YouTube Atta Halilintar terhadap motivasi menjadi seorang Youtuber

3. Seberapa besar pengaruh daya Tarik YouTube Atta Halilintar terhadap motivasi menjadi seorang Youtuber

\section{Metode Penelitian}

Metode yang digunakan adalah metode deskriptif kuantitatif dengan menggunakan survei berupa kuisioner, survei yaitu penelitian yang mengambil sampel dari suatu populasi dan menggunakan kuisioner sebagai alat pengumpulan data yang pokok. Penelitian survei biasanya di lakukan terhadap jumlah sampel yang besar serta fenomena sosial. ${ }^{4}$

Dalam melakukan penelitian data, peneliti menggunakan cara :

1. Kuisioner Tertutup (dengan tiga atau lebih alternatif jawaban)

Kuisioner merupakan teknik pengumpulan data yang dilakukan dengan cara memberi seperangkat pertanyaan atau pernyataan tertulis kepada responden untuk dijawabnya. Kuesioner tertutup merupakan daftar pertanyaan yang

\footnotetext{
${ }^{4}$ Purwanto, Agus E. Metode Penelitian Kuantitatif, (Yoggyakarta : Gaya Media,
} 
alternative jawabannya telah disediakan oleh peneliti seperti "sangat setuju sekali", "sangat setuju", "tidak setuju”, responden dapat langsung membubuhkan tanda centang $(\checkmark)$ dalam kolom yang disediakan

2. Studi Kepustakaan

Studi kepustakaan adalah teknik pengumpulan data dengan mengadakan studi penelaahan terhadap buku-buku, literatur-literatur, catatan-catatan, dan laporan-laporan yang ada hubungan dengan masalah yang ingin dipecahkan.$^{5}$

Dalam penelitian ini, populasi yang digunakan adalah Mahasiswa Ilmu Komunikasi Universitas Singaperbangsa Karawang angkatan 2017-2019 yaitu sejumlah 180 Mahasiswa. Adapun sampel yang diambil dalam dalam pra penelitian yang dilakukan, peneliti mengambil sejumlah mahasiswa yang pernah menonton tayangan YouTube Atta Halilintar yaitu sejumlah 81 orang

Dalam penelitian ini, peneliti menggunakan teknik probability sampling yaitu cluster sampling (Area Sampling) karena karakteristik populasi yang dipakai Dalam penelitian ini adalah Mahasiswa Ilmu Komunikasi Universitas Singaperbangsa Karawang dan peneliti memilih 3 angkatan, yaitu angkatan 2017,2018 dan 2019 dimana populasi yang peneliti pilih merupakan sekelompok mahasiswa yang dijadikan responden bagi peneliti, setiap angkatan mempunyai masing-masing 5 kelas yaitu, kelas A,B,C,D, dan E

\section{Hasil Penelitian Dan Pembahasan}

Pada penelitian ini telah dilakukan proses penyebaran kuesioner kepada mahasiswa dan mahasiswi Ilmu Komunikasi Universitas Singaperbangsa Angakatan 2017-2019 sesuai populasi yang peneliti pakai dalam penelitian ini. Identifikasi responden yang akan disajikan berdasarkan jenis kelamin dan angkatan untuk mengetahui bagaimana hasil dari responden yang akan diteliti. Dari data dibawah ini didapatkan melalui hasil kuesioner yang peneliti sebar kepada responden

\begin{tabular}{|c|c|c|}
\hline Angkatan & Frekuensi & Presentase \\
\hline 2017 & 11 & $13,6 \%$ \\
\hline 2018 & 50 & $61,7 \%$ \\
\hline 2019 & 20 & $24,7 \%$ \\
\hline Jumlah & 81 & $100 \%$ \\
\hline
\end{tabular}

Identifikasi Responden Berdasarkan Angkatan

${ }^{5}$ Nazir, M. Metode Penelitian, (Jakarta : Ghalia Indonesia, 2003),111 
Berdasarkan tabel identifikasi responden berdasarkan angkatan berjumlah 3 angkatan yaitu 2017-2019 sesuai dengan responden yang peneliti pilih dalam penelitian ini, pada angkatan 2018 adalah responden terbanyak yaitu, 50 responden $(61,7 \%)$, responden kedua adalah angkatan 2019 yaitu, memiliki 20 responden $(24,7 \%)$ dan yang terakhir adalah angkatan 2017 yang memiliki frekuensi terendah yaitu 11 responden $(13,6 \%)$

\section{Uji Normalitas}

Uji normalitas digunakan untuk mengetahui apakah data skor tes kelompok kontrol dan kelompok eksperimen berdistribusi normal atau tidak. Hasil output pengujian normalitas dengan Kolmogorov-Smirnov adalah dengan kriteria apabila sig lebih besar dari 0,05

Uji Normalitas

\begin{tabular}{|l|l|c|}
\hline & & $\begin{array}{c}\text { Unstandardize } \\
\text { d Residual }\end{array}$ \\
\hline $\mathrm{N}$ & Mean & 81 \\
\hline $\begin{array}{l}\text { Normal } \\
\text { Parameters }\end{array}$ & Std. Deviation &, 69000000 \\
\hline $\begin{array}{l}\text { Most Extreme } \\
\text { Differences }\end{array}$ & Absolute &, 070 \\
\hline & Positive &, 070 \\
\hline Test Statistic & Negative &,- 067 \\
\hline $\begin{array}{l}\text { Asymp. Sig. } \\
\text { (2-tailed) }\end{array}$ & &, 070 \\
\hline
\end{tabular}

Dari tabel diatas dapat diketahui bahwa nilai sig 0,200 >0,05 melalui hasil dari SPSS 26 for windows artinya nilai sig 2 tailed lebih besar dari 0,05 dan hasilnya dapat diterima. Artinya variabel unstandardized berdistribusi normal.

\section{Uji Multikoliniaritas}

bertujuan untuk menguji apakah dalam model regresi ditemukan adanya korelasi antar variabel bebas. Model regresi yang baik tidak terjadi korelasi antar variabel bebas. Untuk mendeteksi ada tidaknya kolonieritas di dalam model regresi adalah dengan melihat nilai toleransi dan Variance Inflation Factor (VIF). Apabila nilai toleransi $>10 \%$ dan nilai VIF $<10$, maka dapat disimpulkan tidak ada multikolonieritas antar variabel bebas. Berikut adalah perhitungan menggunakan SPSS 26 for windows 
Uji Multikoliniaritas

\begin{tabular}{|c|c|c|c|}
\hline Model & & \multicolumn{2}{|c|}{ Collinearity Statistics } \\
\hline & & Tolerance & VIF \\
\hline $\mathbf{1}$ & (Constant) & & \\
\hline & INTENSITAS X1 &, 987 & 1,013 \\
\hline & ISI PESAN X2 &, 784 & 1,275 \\
\hline & DAYA TARIK X3 &, 794 & 1,260 \\
\hline
\end{tabular}

a. Dependent Variable: MOTIVASI Y

Dari data diatas diketahui melalui hasil SPSS bahwa intensitas X1 untuk nilai VIF $1,013<10$, isi konten memiliki nilai VIF $1,275<10$ dan untuk daya Tarik memiliki nilai VIF 1,260 < 10, artinya nilai VIF dari masingmasing subbvariabel ialah lebih kecil dari 10 dan dapat disimpulkan bahwa tidak ada gejala multikoleniaritas antar variabel independent

\section{Uji Heteroskedastisitas}

Uji heterokedasitas bertujuan menguji apakah dalam regresi terjadi ketidaksamaan variance dari residual suatu pengamatan ke pengamatan yang lain. Heterokedasitas menunjukkan penyebaran variabel bebas. Uji heterokedasitas juga dapat dilakukan dengan uji Glejser. Uji glejser yaitu pengujian dengan meregresikan nilai absolut residual terhadap variabel independent

Uji Heteroskedastisitas

\section{Coefficients $^{\mathrm{a}}$}

\begin{tabular}{|c|l|c|c|}
\hline Model & & T & Sig. \\
\hline $\mathbf{1}$ & (Constant) & 1,091 &, 279 \\
\hline & INTENSITAS X1 &, 714 &, 478 \\
\hline & ISI PESAN X2 &, 283 &, 778 \\
\hline & DAYA TARIK X3 &, 775 &, 441 \\
\hline
\end{tabular}

a. Dependent Variable: Abs_RES 
Dari tabel dapat dilihat melalui SPSS bahwa intensitas memiliki sig 0,478 $>0,05$, isi pesan memiliki nilai sig $0,778>0,05$, dan intensitas memiliki sig $0,441>0,05$, maka dapat disimpulkan bahwa tidak ada gejala heteroskedastisitas, karena nilai signifikan pada tabel diatas harus lebih besar dari 0,05

\section{Analisis Regresi Linear Berganda}

Analisis regresi linear berganda digunakan untuk mengetahui seberapa besar pengaruh hubungan variabel Intensitas $\left(\mathrm{X}_{1}\right)$, Isi pesan $\left(\mathrm{X}_{2}\right)$, Daya Tarik $\left(\mathrm{X}_{3}\right)$ terhadap motivasi menjadi Youtuber $(\mathrm{Y})$

Analisis Linear Berganda

\begin{tabular}{|c|l|c|c|c|}
\hline Model & & \multicolumn{2}{|c|}{$\begin{array}{c}\text { Unstandardized } \\
\text { Coefficients }\end{array}$} & $\begin{array}{c}\text { Standardized } \\
\text { coefficient }\end{array}$ \\
\hline & & \multicolumn{1}{|c|}{ B } & $\begin{array}{c}\text { Etd. } \\
\text { Error }\end{array}$ & Beta \\
\hline $\mathbf{1}$ & (Constant) & 1,576 &, 460 & \\
\hline & $\mathbf{X 1}$ &,- 056 &, 086 &,- 064 \\
\hline & $\mathbf{X} 2$ &, 197 &, 111 &, 192 \\
\hline & $\mathbf{X 3}$ &, 335 &, 086 &, 421 \\
\hline
\end{tabular}

Dari tabel diatas didapatkan hasil dari tabel regresi linear berganda menggunakan SPSS adalah sebagai berikut:

$$
Y=1,576-0,056 X_{1}+0,197 X_{2}+0,335 X_{3}
$$

Persamaan diatas dapat dijelaskan dibawah ini:

1. Koefisien $\mathbf{X}_{\mathbf{1}}=-0,056$

Pada tabel Intensitas $\mathbf{X}_{\mathbf{1}}$ adalah bernilai negatif, sehingga dapat dikatakan bahwa semakin rendah Intensitas tayangan, maka semakin rendah pula motivasi menjadi youtuber terhadap mahasiswa

2. Koefisien $\mathrm{X}_{2}=0,197$

Pada tabel Isi Pesan $\mathrm{X}_{2}$ adalah bernilai positif , sehingga dapat dikatakan bahwa semakin tinggi Isi Pesan maka semakin tinggi pula motivasi menjadi youtuber

3. Koefisien $\mathrm{X}_{3}=0,335$

Pada tabel Daya Tarik $\mathrm{X}_{3}$ adalah bernilai positif, sehingga dapat dikatakan bahwa semakin tinggi Daya Tarik maka semakin tinggi pula motivasi menjadi Youtuber bagi mahasiswa 


\section{Uji F (Simultan)}

Uji F dilakukan untuk melihat keberartian pengaruh variabel independen secara simultan terhadap variabel dependen atau sering disebut kelinieran persamaan regresi.

\section{Uji F (Simultan)}

ANOVA $^{\mathrm{a}}$

\begin{tabular}{|l|l|r|r|r|r|r|}
\hline \multicolumn{2}{|c|}{ Model } & \multicolumn{1}{c|}{$\begin{array}{c}\text { Sum of } \\
\text { Squares }\end{array}$} & \multicolumn{1}{c|}{ df } & \multicolumn{1}{c|}{$\begin{array}{c}\text { Mean } \\
\text { Square }\end{array}$} & \multicolumn{1}{c|}{ F } & \multicolumn{1}{c|}{ Sig. } \\
\hline $\mathbf{1}$ & $\begin{array}{l}\text { Regressio } \\
\text { n }\end{array}$ & 15.824 & 3 & 5.275 & 10.371 & $.000^{\mathrm{b}}$ \\
\cline { 2 - 7 } & Residual & 39.163 & 77 & .509 & & \\
\hline & Total & 54.988 & 80 & & & \\
\hline
\end{tabular}

Dari tabel untuk uji $\mathrm{F}$ dapat diketahui bahwa nilai untuk $\mathrm{F}$ hitung adalah $10,371>2,72$ dari F tabel dan sig $=0,000<0,05$ maka, secara simultan berarti variabel independent atau variabel bebas untuk Intensitas $\mathrm{X}_{1}$, Isi pesan $\mathrm{X}_{2}$ dan Daya Tarik $\mathrm{X}_{3}$ artinya berpengaruh signifikan terhadap variabel motivasi $\mathrm{Y}$ menjadi Youtuber

\section{Uji T (Parsial)}

Uji T dilakukan untuk mengetahui apakah individu (parsial) secara variabel independent mempengaruhi variabel dependent secara signifikan atau tidak, berikut adalah hasil dari data yang dikelola menggunakan SPSS

Uji T (Parsial)

\begin{tabular}{|c|c|c|c|}
\hline Model & & T & Sig. \\
\hline $\mathbf{1}$ & (Constant) & 3.426 & .001 \\
\hline & INTENSITAS X1 & -.656 & .514 \\
\hline & ISI PESAN X2 & 1.767 & .081 \\
\hline & DAYA TARIK X3 & 3.903 & .000 \\
\hline
\end{tabular}

a. Dependent Variable: MOTIVASI Y

Ho diterima dan Ha ditolak apabila t hitung $<$ ttabel atau sig $>0,05$

Ho ditolak dan $\mathrm{Ha}$ diterima apabila $\mathrm{t}$ hitung $>$ ttabel atau sig $<0,05$

Hasil pengujian statistik dengan SPSS pada Intensitas $\mathrm{X}_{1}$ diperoleh nilai thitung $=-0,656<$ tabel $=1,994$ dan nilai signifikasi (sig) 0,514 >0,05. Maka dapat disimpulkan Ho diterima dan Ha ditolak, yang artinya variabel intensitas menonton tayangan YouTube $\mathrm{X}_{1}$ tidak berpengaruh signifikan terhadap motivasi menjadi youtuber 
Hasil pengujian untuk Isi Pesan $\mathrm{X}_{2}$ menggunakan SPSS diperoleh nilai thitung $=1,767<$ ttabel $=1,994$ dan nilai signifikasi (sig) 0,081 >0,05, maka dapat disimpulkan Ho diterima dan Ha ditolak, yang artinya variabel Isi Pesan X2 tidak berpengaruh signifikan terhahadap motivasi menjadi youtuber

Hasil pengujian untuk Daya Tarik $\mathrm{X}_{3}$ menggunakan SPSS diperoleh nilai thitung $=3.903>$ ttabel $=1,994$ dan nilai signifikasi (sig) $0,000>0,05$, maka dapat disimpulkan Ho dditolak dan Ha diterima, yang artinya variabel Daya Tarik X3 berpengaruh signifikan terhadap motivas menjadi youtuber

\section{Koefisien Determinasi Ganda}

Untuk mengetahui besarnya variabel bebas terhadap variabel dependent dapat dilihat dalam tabel model summary sebagai berikut

Koefisien Determinasi Ganda

\begin{tabular}{|l|r|r|r|r|c|}
\hline \multicolumn{7}{|c|}{ Model Summary $^{\mathbf{b}}$} \\
\hline Model & \multicolumn{1}{|c|}{ R } & R Square & $\begin{array}{c}\text { Adjusted R } \\
\text { Square }\end{array}$ & $\begin{array}{l}\text { Std. Error of } \\
\text { the Estimate }\end{array}$ & $\begin{array}{c}\text { Durbin- } \\
\text { Watson }\end{array}$ \\
\hline 1 & $.536^{\mathrm{a}}$ & .288 & .260 & .713 & 2.258 \\
\hline
\end{tabular}

Pada tabel mendapatkan hasil dari SPSS dan dapat dijelaskan bahwa R2 Adjusted R Square yaitu sebesar 0,260. Hal ini dapat diartikan bahwa variabel indepedenden yaitu Intensitas, Isi Pesan dan Daya Tarik dapat mennjelaskan variabel dependen yaitu motivasi menjadi youtuber sebesar $26,0 \%$, sedangkan sisa persentasenya dipengaruhi variabel lain yang tidak dikaji dalam penelitian 


\section{Koefisien Determinasi Parsial $\left(\mathbf{r}^{2}\right)$}

Koefisien Determinasi Parsial

\begin{tabular}{|l|c|c|c|}
\multicolumn{1}{|c}{ Model } & \multicolumn{3}{c|}{ Coefficients $^{\mathbf{a}}$} \\
\cline { 2 - 4 } & Zero-order & Partial & Part \\
\hline (Constant) & & & \\
\hline INTENSITAS X1 & -.032 & -.075 & -.063 \\
\hline ISI PESAN X2 & .376 & .197 & .170 \\
\hline DAYA TARIK X3 & .507 & .406 & .375 \\
\hline
\end{tabular}

\section{a. Dependent variable Motivasi Y}

Pada tabel diatas merupakan hasil dari perhitungan SPSS dapat diketahui besarnya pengaruh terhadap Intensitas tayangan terhadap motivasi menjadi youtuber adalah $-0,075^{2}=0,56 \%$. Besarnya pengaruh isi pesan terhadap motivasi menjadi youtuber adalah $0,197=3,88 \%$. Besarnya pengaruh untuk daya Tarik terhadap motivasi menjadi youtuber adalah $0,406=16,48 \%$

Berdasarkan hasil penelitian dengan menyebarkan kepada 81 Mahasiswa Program Studi Ilmu Komunikasi UNSIKA sebagai sampel responden pada penelitian ini, peneliti telah menguji untuk mengetahui seberapa besar pengaruh intensitas, isi pesan dan daya Tarik tayangan Youtube Atta Halilintar terhadap motivasi menjadi youtuber bagi mahasiswa Angkatan 2017-2019. Adapun teori yang dipakai oleh peneliti teori pembelajaran sosial oleh Albert Bandura ${ }^{6}$, dimana teori ini sangat berperan dalam mempelajari efek dari media massa pada khalayak melalui proses pembelajaran hasil pengamatan yang dilihat, yaitu observationl learning atau proses belajar dengan mengamati. Albert Bandura membaginya dalam 4 tahapan yaitu, (Proses Perhatian), bagaimana seseorang tersebut mengamati sebuah peristiwa melalui proses perhatian seperti sikap atau tindakan sesorang dalam menonton sebuah tayangan dalam channel youtube Atta Halilintar, kedua (Proses Mengingat), seseorang akan menyimpan Kembali halhal yang menarik dalam memorinya seperti dalam menonton sebuah tayangan dalam channel YouTube Atta Halilintar seseorang tersebut akan mengingat hal yang menarik pada content YouTube yang disajikan, ketiga (Proses Reproduksi Motoris), sesorang akan menyatakan Kembali ingatannya yang telah disimpan dalam memorinya, keempat (Proses Motivasi) mendorong perilaku sesorang pada suatu tujuan tertentu, seperti pada penelitian ini akan mendapatkan hasil

\footnotetext{
${ }^{6}$ Bandura,Albert . Social Learning Theory, (New York: General Learning Press,
} 
mengenai tayangan YouTube berpengaruh signifikan atau tidak terhadap motivasi menjadi menjadi youtuber oleh Mahasiswa. Dalam penelitian ini Hasil dalam uji regresi linear berganda didapatkan persamaan sebagai berikut: $Y=$ $1,576-0,056 X_{1}+0,197 X_{2}+0,335 X_{3}$

Berdasarkan hasil penelitian didapatkan keterangan bahwa ketiga variabel untuk intensitas, isi pesan dan daya Tarik tayangan youtube Atta Halilintar tersebut berpengaruh signifikan terhadap motivasi menjadi youtuber. besarnya pengaruh variabel tersebut adalah $26,0 \%$, fakta-fakta ini menunjukan bahwa ketiga variabel tersebut merupakan aspek yang cukup dominan dalam mempengaruhi motivasi untuk menjadi seorang youtuber Hasil penelitian dalam determinasi menunjukan hasil bahwa intensitas tayangan YouTube Atta Halilintar memperoleh hasil sebesar $0,56 \%$ yang artinya intensitas tayangan YouTube Atta Halilintar tidak berpengaruh signifikan terhadap motivasi menjadi Youtuber

Hasil penelitian menunjukan bahwa untuk isi pesan tayangan YouTube Atta terhadap motivasi menjadi youtuber memperoleh hasil sebesar 3,88\% yang artinya untuk uji $\mathrm{T}$ parsial adalah untuk isi pesan yang disampaikan dalam tayangan YouTube Atta Halilintar tidak berpengaruh signifikan terhadap responden

Hasil penelitian untuk variabel daya Tarik tayangan YouTube Atta Halilintar terhadap motivasi menjadi seorang youtuber memperoleh hasil sebesar 16,48\%, hal ini menunjukan bahwa daya Tarik dalam tayangan youtube Atta telah menarik perhatian responden dengan berbagai content-content yang dikemas secara menarik, serta hasil yang memuaskan mengenai visualisasi effect yang dikemas secara menarik sehingga membuat responden yang menonton tertarik, artinya untuk variabel daya Tarik tayangan youtube Atta Halilintar berpengaruh signifikan terhadap motivasi menjadi seorang youtuber

\section{Penutup}

\section{Simpulan}

Berdasarkan hasil penelitian dan pembahasan diatas dapat diambil simpulan sebagai berikut:

1. Berdasarkan hasil pengujian untuk hipotesis sub variabel intensitas X1, ditemukan hasil yang menunjukan bahwa intensitas tidak berpengaruh signifikan terhadap motivasi menjadi seorang youtuber bagi mahasiswa program studi ilmu komunikasi UNSIKA Angkatan 2017-2019. Hasil intensitas yang menunjukan hasil tidak berpengaruh signifikan terhadap motivasi menjadi youtuber dikarenakan nilai signifikansi lebih besar dari 0,05 dan untuk nilai $\mathrm{T}$ hitung diperoleh hasil yang lebih kecil dari T tabel, yaitu thitung $=-0,656<$ tabel $=1,994$ dan nilai signifikasi (sig) 0,514 > 0,05. Dan diperoleh hasil untuk determinasi parsial adalah sebesar 0,56\% Maka dapat disimpulkan Ho diterima dan Ha ditolak yang artinya tidak 
berpengaruh signifikan untuk intensitas tayangan YouTube Atta Halilintar terhadap motivasi menjadi youtuber.

2. Berdasarkan hasil pengujian untuk hipotesis sub variabel isi pesan $\mathrm{X} 2$, ditemukan bahwa hasil yang menunjukan isi pesan tayangan YouTube Atta Halilintar tidak berpengaruh signifikan dikarenakan nilai signifikansi lebih besar dari 0,05 Dan nilai $\mathrm{T}$ hitung lebih diperoleh hasil yang lebih yaitu, thitung $=1,767<$ tabel $=1,994$ dan nilai signifikasi (sig) $0,081>0,05$, maka dapat disimpulkan Ho diterima dan $\mathrm{Ha}$ ditolak dan diperoleh hasil determinasi parsial sebesar 3,88\% yang artinya untuk isi pesan tayangan youtube Atta Halilintar tidak berpengaruh signifikan terhadap motivasi menjadi youtuber

3. Berdasarkan hasil pengujian hipotesis sub variabel daya Tarik X3 , ditemukan bahwa hasil untuk daya Tarik tayangan YouTube Atta Halilintar menunjukan pengaruh yang signifikan terhadap motivasi menjadi youtuber karena untuk nilai signifikansi lebih kecil dari 0,05 dan untuk T hitung lebih besar dari $\mathrm{T}$ tabel yaitu nilai thitung $=3.903>$ tabel $=1,994$ dan nilai signifikasi (sig) 0,000 > 0,05, maka dapat disimpulkan Ho dditolak dan $\mathrm{Ha}$ diterima dan diperoleh hasil determinasi parsial sebesar 16,48\%yang artinya untuk daya Tarik tayangan YouTube Atta Halilintar memberikan kesan baik untuk responden karena content-content yang dikemas secara menarik serta kolaborasi dengan para public figure/artis terkenal dan visualisasi effect yang menjadikan daya tarik tersendiri bagi channel YouTube Atta Halilintar sehingga responden tertarik untuk menontonnya.

Berdasarkan uji yang telah dilakukan oleh peneliti, peneliti mendapatkan kesimpulan bahwa untuk intensitas, isi pesan dan daya Tarik berpengaruh signifikan secara simultan untuk $\mathrm{F}$ hitung adalah 10,371 $>2,72$ dari $\mathrm{F}$ tabel dan sig $=0,000<0,05$ artinya untuk $\mathrm{X}_{1}, \mathrm{X}_{2}, \mathrm{X}_{3}$ memiliki pengaruh yang signifikan terhadap motivasi menjadi youtuber

\section{Saran}

1. Dari segi intensitas dalam menggunakan media seperti YouTube memang sebaiknya kita sebagai pengguna yang baik dapat lebih bijak lagi untuk mengurangi intensitas penggunaan media sosial YouTube, , karena ketika kita terlalu berlebihan dalam intensitas menggunakan sosial media seperti YouTube maka kita akan merugikan diri sendiri, seperti menatap layar hp terlalu lama mata kita menjadi kurang sehat dan akan memiliki kecanduan untuk terus-menerus menggunakan media sosial

2. Dari segi isi pesan, didalam tayangan YouTube Atta Halilintar memang isi pesan yang disampaikan bersifat ringan dan mudah untuk dimengerti sehingga dapat mengibur penonontonnya, kita sebagai penonton pun harus bijak dalam mengambil hal-hal positif yang disampaikan dalam tayangan YouTube Atta

3. Dari segi daya Tarik didalam YouTube Atta Halilintar memang berbeda dari channel lain, karena visualisasi effect dan backsound music yang dikemas 
secara. Dalam tayangan YouTube Atta penonton diharapkan dapat lebih bijak dalam mengambil sisi positif baik pada tayangan YouTube Atta ataupun karakter dari Atta Halilintar sendiri, karena ini juga bisa menjadi motivasi untuk kita agar lebih kreatif Ketika kita ttertarik menjadi seorang content creator dan tentunya harus memiliki nilai yang positif dan bermanfaat bagi penontonnya.

4. Saran bagi peneliti selanjutnya, ada beberapa saran yang perlu diperhatikan bagi peneliti selanjutnya yang tertarik dalam meneliti pengaruh tayangan YouTube terhadap motivasi menjadi youtuber adalah: peneliti selanjutnya diharapkan dapat mengkaji lebih banyak sumber maupun referensi secara jelas terkait dengan pengaruh tayangan YouTube terhadap motivasi menjadi youtuber agar hasilnya dapat lebih baik, jelas dan lengkap

\section{Daftar Pustaka}

Arikunto, S. Prosedur Penelitian, Suatu Pendekatan Praktek, (Jakarta : PT Rineka Cipta, 2002)

Arsyad.Karakteristik Media Pembelajaran,(Jakarta: PT Raja GarfindoPerasada, 2002)

Bandura,Albert . Social Learning Theory, (New York : General Learning Press, 1971)

Mulyana, Deddy. Ilmu Komunikasi Suatu Pengantar. (Bandung: Remaja Rosdakarya, 2012)

Nasrullah, Ruli. Media Sosial, (Bandung: Simbiosa Rekatama Media, 2015)

Nazir, M. Metode Penelitian, (Jakarta : Ghalia Indonesia, 2003)

Purwanto, Agus E. Metode Penelitian Kuantitatif, (Yoggyakarta : Gaya Media, 2007)

Sugiyono. Metode Penelitian Kuantitatif, Kualitatif, dan R\&D, (Bandung : CV Alfabeta, 2010)

Sugiyono. Metode Penelitian Kuantitatif, Kualitatif dan R\&D, (Bandung : CV Alfabeta, 2012)

Sugiyono. Metode Penelitian Kuantitatif, Kualitatif dan R\&D. (Bandung : CV Alfabeta, 2016)

Widjajanto, Kenmada, dkk. Perencanaan Komunikasi : Konsep Dan Aplikasi. (Bandung : Ultimus, 2013) 
154 Jurnal Dakwah dan Komunikasi. Vol 5 no 2, 2020

\section{Internet :}

wnw.youtube.com

Hootsuite (We are Social): Indonesian Digital Report 2019 